\title{
Cancer of the eyelids in albinos
}

\section{Wilson IB Onuigbo*}

Department of Pathology, Medical Foundation \& Clinic, Nigeria

*Corresponding author: Wilson IB Onuigbo, Department of Pathology, Medical Foundation \& Clinic, Enugu, 400001.

Submission: 㭗 April 07, 2018; Published: 僵 May 29, 2018

\section{Abstract}

A report from South Africa emphasized the occurrence of squamous cell carcinoma among the Black albinos. Elsewhere, with a colleague, the case was presented of an albino having in one facial microscope slide as many as 3 different carcinomas. Here, the eyelids are singled out to demonstrate the pattern found personally among albinos of the Ibo ethnic group. While squamous cell carcinoma preponderated, adenocystic, undifferentiated and basal cell cases featured.

Keywords: Skin; Albino; cancer; Eye lids; Nigeria

\section{Introduction}

From South Africa, Lekalakala's associates argued strongly the case for squamous cell carcinoma developing in Black albinos in sub-Sahara Africa [1]. Elsewhere, with a colleague, we exemplified the case in which one microscope slide exposed the presence in an albino's face of squamous cell carcinoma, adenocystic carcinoma, and basal cell carcinoma [2]. Accordingly, just as a Blantyre group chanced on an albino woman aged 27 years whose affliction included the eye lid [3], let me expatiate on a dozen patients with such lid.

\section{Investigation}

Following the lead of a Birmingham (UK) group, which postulated that the establishment of a histopathology data pool facilitates epidemiological analysis [4], let me utilize such an Institution established by the Government of the then Eastern Region of Nigeria at Enugu. In particular, I was the pioneer pathologist from 1970. Perhaps, the tabular approach will suffice since I kept personal copies of every case.

\section{Results}

At a glance, the age range was 16 to 60 years (mean 36 years); males preponderated in the ratio of $2: 1$, and so did the right side. Similarly, the upper eye lid was more often afflicted. On the whole, much as the squamous cell were more numerous, adenocystic carcinoma, undifferentiated carcinoma, basisquamous, and basal cell carcinoma featured(Table 1).

Table 1: Epidemiological data on albino eyelid lesions.

\begin{tabular}{|c|c|c|c|c|c|c|}
\hline No & Initials & Age & Sex & Side & Level & Carcinoma type \\
\hline 1 & OV & 40 & $\mathrm{M}$ & $\mathrm{R}$ & Upper & Squamous \\
\hline 2 & NA & 32 & M & $\mathrm{R}$ & - & Adenocystic \\
\hline 3 & EJ & 47 & $\mathrm{~F}$ & Both & Upper & $\begin{array}{l}\text { Undifferentiated/ } \\
\text { Adenocystic }\end{array}$ \\
\hline 4 & IM & 30 & M & $\mathrm{L}$ & Upper & Squamous \\
\hline 5 & OG & 41 & $\mathrm{~F}$ & $\mathrm{R}$ & Lower & Squamous \\
\hline 6 & $\mathrm{AK}$ & 38 & $\mathrm{~F}$ & Both & - & Squamous \\
\hline 7 & UP & 30 & $\mathrm{~F}$ & $\mathrm{R}$ & Upper & Squamous \\
\hline 8 & UR & 16 & M & $\mathrm{L}$ & Upper & Basisquamous \\
\hline 9 & MA & 60 & M & $\mathrm{R}$ & Upper & Squamous \\
\hline 10 & CJ & 37 & M & $\mathrm{R}$ & Upper & Basal cell \\
\hline 11 & ER & 41 & M & $\mathrm{R}$ & Lower & Squamous \\
\hline 12 & NA & 20 & M & $\mathrm{R}$ & Lower & Undifferentiated \\
\hline
\end{tabular}




\section{Discussion}

A report, which dealt with the incidence of eyelid basal cell carcinoma in England 2000-2010, concerned as many as 33,610 recorded cases [5]. Surely, this is a far cry in contrast with the local single example in an albino! By way of comparison, it was emphasized that squamous cell carcinoma in the eyelid in USA [6], "occurs most commonly in elderly, fair-complexioned individuals." This is reminiscent of the local experience among the albinos.

A general impression is the one made from the background of Kenya [7], thus: "Therefore, appropriate physical protection, avoiding any trauma when carrying sharp, heavy or rough instruments by the shoulder and hands, and finally urgent and quality treatment for any lesion even a small erosion and ulcer, especially on exposed areas in albinos, are recommended." However, I am persuaded that these steps are not enough [8]. In sum, my arguments differed [9]. In this context, I gave the example of the famous government intervention in the UK which ended the chimney sweepers scrotal cancer by altogether abolishing the trade! In other words, if the Government of Nigeria or elsewhere offers indoor employment to albinos statutorily, albino skin cancer will become a thing of the past!

\section{References}

1. Lekalakala PT, Khammissa RAG, Kramer B, et al. (2015) Oculocutaneous albinism and squamous cell carcinoma of the skin of the head and neck in sub-Sahara Africa. J Skin Cancer 2015: 167847.

2. Onuigbo WIB, Nnabuko RE (2009) Three different carcinomas clustered in one facial focus in albino. Nig J Surg Sci 19: 38-40.

3. Mapurisa G, Masamba L (2010) Locally advanced skin cancer in an albino, a treatment dilemma. Malawi Med J 22(4): 122-123.

4. Macartney JC, Rollaston TP, Codling BW (1980) Use of a histopathology data pool for epidemiological analysis. J Clin Pathol 33(4): 351-353.

5. Saleh Gm, Desai P, Collin JRO, Ives A, Jones T, et al. (2017) Incidence of eyelid basal cell carcinoma in England: 2000-2010. Br J Ophthalmol 101(2): 209-212.

6. Reifler DM, Hornblass A (2002) Squamous cell carcinoma of the eyelid. Survey Ophthalmol 30(6): 349-365.

7. Emadi SE, Sule JA, Babamahmoodi R, et al. (2017) Common malignant cutaneous conditions among albinos in Kenya. Med J Islam Repub Iran 31: 3 .

8. Wilson Onuigbo (2015) No albino should suffer from extensive skin cancer let alone die there-from. J Cancer Prev Curr Res 2(3): 00040.

9. Onuigbo WIB (2015) The influence of Pott's irritation theory of occupational cancer during the 19th Century: A review with hypothesis on albinism sunlight induced cancer. J Cancer Prev Curr Res 2(5): 00053.
Creative Commons Attribution 4.0 International License

For possible submissions Click Here

\section{Submit Article}

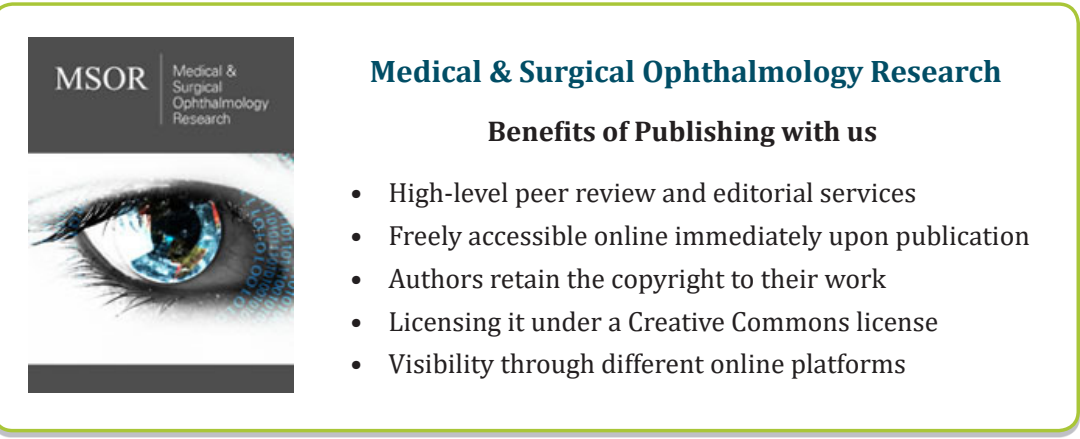

